\title{
A WALK ABOUT THE CITY: \\ STALKER, THE TRANSURBANCE AND THE CITY MAP
}

By Danielle Wiley

In the spring of 2007, I joined a group of urban activists called Stalker on a walk along the Tiber River in Italy. The walk, conducted over 12 weeks, began in the ancient port city of Ostia, where the mouth of the Tiber meets the Tyrrhenian Sea, continued north-east through the centre of Rome, and ended at the far edge of Rome's greater metropolitan region. Stalker's Tiber walk was a so-called "transurbance," a mode of critical walking created by the collective. Transurbances are walks in the leftover spaces in and around the contemporary metropolis, which Stalker calls “actual territories.” In the transurbance, walking is both a mode of expression and a useful instrument for learning about the ongoing social and morphological transformations in cities.

Stalker's transurbance of the Tiber was more specifically a means of engaging the individuals and communities living illegally along the riverbanks, and then conveying aspects of their living conditions to the public. Stalker was accompanied by architecture students whose aim was to produce an atlas of the riverbanks, describing the spaces and qualities of this urban environment that are typically excluded from city maps. In this context the transurbance is a kind of oppositional map, where the map is understood in two senses: as a process of investigating a territory (“mapping” as a verb) and a means of representation (a “map” as noun).

The Rome-based collective was first formed during a walking project. In October 1995, a group of 8 young architects, artists, videographers and an astrophysicist, circumnavigated the city of Rome on foot. The walk, called the Giro di Roma (Walk about Rome), was intended to 
provoke debate about the city's peripheries. Against a dominant image of Rome - that is, of a deeply historical, mono-cultural city - the Giro di Roma produced counter-images of open countryside, unfinished industrial structures hosting squatter settlements, multilane highways intersecting Roman aqueducts, even roaming sheep. Local journalists trailing the walkers dubbed the group "Stalker," after the character in Tarkovsky’s 1979 film of the same name who guides adventurers into a post-apocalyptic territory (Lang, 2007). However, the moniker also underlines the ethical complexity of Stalker's position within a sensitive terrain. One member of the group, Lorenzo Romito, wrote this journal entry upon return:

Every time we climbed over a wall or we went through a hole in a chain-link fence, we experienced apprehension, which made us more attentive to these unknown places, even if they are in our backyard. These existing terrains have been unveiled. We have the key to their access; we know where to return to listen to the voices ... but also to conduct any others who might feel the need to discover them. $(1997,140)$

Romito's diary is striking for its lack of reflexivity on Stalker's position within a sensitive terrain. The passage positions Stalker if not as colonizers then as tour guides. To whom were these places unknown? For whom were they unveiled? This "veiled" territory around Rome was in fact inhabited by tens of thousands of people. While the Giro di Roma corralled public pressure for improved services in Rome’s periphery, it also risked exposing marginal communities to exploitation or forcible removal. Nonetheless Romito was not mistaken - the city's periphery did endure a very real kind of invisibility. The absence of media coverage and public debate at the time revealed a lack of awareness about Roma and refugee communities 
growing outside the city. By walking in these so-called "unknown places," the Giro di Roma drew questions of the city's identity to the fore.

Since the Giro di Roma, Stalker conducted transurbances in the peripheries of Milan, Paris, Berlin, Turin, Passaic and Sarajevo, before recently turning their attention back to Rome and the Tiber River. Inevitably, the collective has substantially changed in the 13 years between the Giro di Roma and the Tiber walk. The collective has gained knowledge of the particular political and material conditions in which marginal peoples in Europe live. They have built a savvy relationship with local and international media. They invite journalists to participate in their initiatives only once a strong relationship has been established between the group and the local community, and step aside to allow community members to engage directly with the media. Members who have by now entered university faculties leverage this position to engage students and the public in issues of urban marginalization. Most importantly, the group's dual commitment to research and activism has allowed them to develop a clearer conceptualization of walking as a critical practice, capable of aesthetic and social transformations of a landscape.

Here I want to consider the theoretical underpinnings of the transurbance, with the aim of exploring the role that walking might play in revaluating urban space.

\section{Walking and Political Resistance}

The transurbance can be situated within a history of critical walking as a symbolic, political and aesthetic practice. In thinking about the transurbance, Stalker drew on many historical points of reference, including Baudelaire's flâneur, Dadaist's visit excursions, the Surrealist deambulateur, Richard Long's land art and de Certeau's everyday pedestrian. But the 
clearest precedent for Stalker’s transurbance was the dérive. The concept of the dérive was developed by Guy Debord, a founding member of the French Lettrist and Situationist International societies. The Lettrists and later the SI aimed to develop a mode of walking in the city which could make one attuned to the city's unconscious while at the same time achieving a heightened political awareness. The premise of the dérive is that the city has a psychogeography, in which each zone in the city has a particular mood and also a particular configuration of power relations. The dérive was an aesthetic-political tool to describe this psychogeography, and to bring to light the functioning of the capitalist power in urban space.

The dérive, like the transurbance, is a mode of mapping, designed to undermine the normative cartography of the State. According to Guy Debord, the State recodes the city as a controllable image-object through particular representational practices, including aerial photography, totalizing perspectives and topographic surveys (1958). The dériviste refuses the State's rational perspective and instead opts for an affective immersion in the urban fabric. Under the omnipotent eye of the State, the dérive adopts a willful blindness. Because the dérive "took place literally below the threshold of visibility of that aerial overview, beyond what is visible to the sociologist-voyeur's gaze," it evaded discovery by the State (McDonough, 255).

Stalker's transurbance has much in common with the SI's dérive. Both aim to register urban conditions that typically go unseen: the dérive maps the city's subtle atmospheres, whereas the transurbance maps emerging socio-spatial conditions. A key difference between the dérive and the transurbance is location. The SI searches out liminal aspects of space within the heart of the city. Stalker's attention, on the other hand, is focused on the "outside" of the city - on places that are neglected by the State and the general public, but have been appropriated through unregulated inhabitation. The goal of the transurbance is to incorporate these marginalized 
spaces into the city’s territory and self-image. In their 1996 manifesto, Stalker describes these locations of abandonment around and inside the contemporary city as "immanent." These socalled "actual territories" have a capacity to generate new forms and experiences in the city: Actual Territories constitute the built city's negative, the interstitial and the marginal, spaces abandoned or in the process of transformation. These are ... the unconscious becoming of urban systems, the spaces of confrontation and contamination between the organic and the inorganic, between nature and artifice. (Stalker, www.stalkerlab.it)

Walking is a means by which to witness these spaces, which, according to Stalker, anticipate the future form of the city.

\section{Walking, Narrative and Identities}

Another important reference point for Stalker's transurbance is philosopher Michel de Certeau's theorization of walking as a means of agency. For de Certeau, walking in the city is a means of "enunciating space" - that is, of both creating and legitimizing urban territories (1998, 92). Unlike the SI, de Certeau doesn't reserve the revolutionary power of walking for the artist/activist. In The Practice of Everyday Life, he describes the everyday walking of citizens as a creative force. By redefining the urban fabric in relation to human action rather than economic exchange, walking converts the property value of urban space into use-value. To counter Foucault's analysis of the omnipotence of the modern disciplinary society, de Certeau argues that "microbe-like" walkers swarm the urban fabric and infiltrate the networks of surveillance of the city. 
De Certeau opposes the multitude of everyday walkers to the singular figure of the modern "voyeur." The voyeur is like an observer in a skyscraper who assumes omniscience of the city, but is in fact deeply alienated. De Certeau's critique of the modern voyeur is congruent with the SI's critique of modern cartography: to view the city from above is to possess it as an object and convert it into a simulacrum. He agrees with Debord that aerial surveillance is emblematic of capitalism. The voyeur is a modernist city planner, who assumes the god-like position of seeing the city "as a whole," but risks annihilating that which he aims to possess. If the aerial view visualizes the city as an abstract, geometricized place, pedestrian movements convert these places into material, "lived” spaces.

For de Certeau, the pedestrian appropriates the urban spatial system like a speaker takes on a language - the walker thus "speaks" the spaces of the city $(1998,97)$. Stalker draws on this idea of the enunciative function of walking in their conception of the transurbance. The aim of the transurbance is to act within the language of the "actual territories," which exists a priori to the walkers. Stalker describes the crossing and re-crossing of the unseen areas in the city as composing a terrain and relating it back to a general consciousness. The spatial practices of walking and mapping, united in the transurbance, thus have an important narrative dimension. The transurbance is, in de Certeau's terms, a "spatial story." De Certeau argues that the primary function of the spatial story is to found - that is, to authorize the establishment, displacement or transcendence of limits of a territory. Narrative prepares the ground for the action it describes. Through a narrativistic walking, Stalker symbolically opens the "actual territories” to future action.

Walking and other quotidian activities of city dwellers compose spatial stories, which are a small, but cumulative, means of resisting the dominant narrative of the State. Spatial stories 
describe a frontier in order to articulate a relationship between a legitimate interior space and its alien exterior (de Certeau, 1998, 130). The paradox of the frontier is that it joins as much as it separates. Crucially, the frontier allows the element of alterity to cross into legitimate space. An important aim of the Tiber transurbance was to enunciate the presence of the alien within the legitimate space of the city of Rome. These were illegal immigrants as literal aliens, but also alien aspects of the city, such as ad hoc farming and fishing, impassable underbrush, industrial ruins and concealed shelters.

The transurbance is akin to what de Certeau calls a "delinquent" story. In a contemporary society with few symbolic outlets, the delinquent story offers the possibility of drifting from social discipline. If a story is activated by oppositional relationships between the familiar and the alien, then a territory might be (in Stalker's terms) actuated by the contradictory conditions of "becoming” and abandonment, and of virginity and mutation. Stalker's transurbance along the Tiber's riverbanks was a negotiation between the micro-stories of innumerable "paperless" Romanians, Albanians, Kurdish and Roma communities, and the dominant narrative of Rome.

\section{Walking and learning the "outside" of the city}

I have suggested that "actual territories," such as the periphery of Rome or its riverbanks, are exterior to the city’s self-image and "general” consciousness. In their early theorizations of the “actual territories”, Stalker drew heavily on Deleuze and Guattari’s concept of the plateau, as a purely exterior space outside of the State. Deleuze and Guattari describe the plateau as a nomadic, "smooth" space, opposed to the State’s "striated” interior. The term 
"striated" is derived from stringere: to draw tight. "Smooth" space, by contrast, is not to be interpreted as homogeneous but as without boundaries or constrictions (Dovey, 115).

Here the context of Stalker's first transurbance, the Giro di Roma, comes forward with particular clarity, as Rome is in many ways an ideal model of striated space. As early as Bramante's time, it was argued that Rome existed only through the interrogations of its ruins. Arguably, the excavation of the fossilized Classical, Renaissance and Baroque cities covers over the site where a living city would become (Purini, 2000). Given the extreme constriction of the historic core, the Roman periphery would have appeared to a group of young architects and artists as "smooth" space of potentiality. If the future of the centre of Rome lies in its past, then the "actual territories" in its margins are powerful if only because they are open to a future.

A common critique of Deleuze and Guattari's theorization of the plateau is that it is incommensurable with existing marginalized places, which do not enjoy the freedom from State domination and colonial hegemony that is ascribed to the idealized version. The question is raised of how the theoretical, absolute freedom of the plateau can be re-connected to an existing social system. This same critique might fairly be directed to Stalker's transurbances, undertaken by a group of mainly middle-class young men from Italian families. It is certainly arguable that the Roman periphery was "invested with subversive or destabilizing power by the visitors," and not by the locals. Nonetheless, Stalker’s consciously avoids Deleuze and Guattari’s vocabulary of the plateau; their choice of the term of "actual" underlines their desire to locate their projects in real places. Stalker's theorizations of the "actual territories" have by now developed through a decade of transurbances and community partnership projects of increasing scale and complexity, including “Campo Boario,” a long-term mediation project between an Albanian and Kurdish refugee squatter settlement and the Comune di Roma, and “Transborderline," a traveling art 
installation that creates, symbolically, a porous and hospitable national border. In another initiative, Stalker worked for one year with the residents of Corviale, a so-called "failed" social housing project in Rome's periphery, to help them to transform their living conditions and their image in the public’s eye, and to negotiate the building's redevelopment with the Comune.

Through their ongoing research and engagement with residents of the "actual territories," Stalker has developed a much more nuanced theoretical model of the contemporary city, in which the margin is not assumed to be absolutely exterior to a centre. Francesco Careri, one of Stalker's writers, notes that from a bird's eye view of many cities today, one would have difficulty discerning a centre and a margin.

What we thought was a compact city is actually filled with holes, often inhabited by different ethnic groups. If we get lost, we cannot easily figure out how to head toward an outside or an inside... Instead we are faced with a sort of leopard skin with empty spots inside the city and full spots in the middle of the countryside. (2002, 186)

Careri describes this contemporary urban formation as an “archipelago,” a system of densely urbanized nodes interconnected by open areas. The archipelago city takes us beyond a false division of nomadic space and settled space. Careri suggests that every real place is a mixture of smooth and striated space in a reciprocal relation, creating a range of hybrid conditions. It is the open "seas" of the archipelago city, often misrecognized as "urban voids," that are crossed in the transurbance. The transurbance affirms these so-called "voids" as fundamental to the urban system - as spaces where people grow vegetables without a permit, walk their dogs, look for shortcuts between neighbourhood or have a picnic. 
Because the activities and inhabitations in these spaces are transient, the best way to learn about the "actual territories" is to move through them. Through the transurbance, the city is described from an "aesthetic-experiential point of view. To recognize a geography within the supposed chaos of the peripheries ... (we use) the aesthetic form of the ...journey” $(2002,184)$. Careri compares an experiential mode of orientation in the city to the mapping practices of nomadic peoples such as the Australian Maori. The nomadic map orients a walker to a terrain which to the settler's eyes appears empty, but to the nomad is full of traces. Similarly, an "urban void" of the contemporary city is not empty at all but contains a range of spatial conditions and identities. Careri describes the contemporary European metropolis as a hybrid:

(T)oday's city contains nomadic spaces (voids) and sedentary spaces (solids) that exist side by side in a delicate balance of reciprocal exchange. Today the nomadic city lives inside the stationary city, feeding on its scraps and offerings, in exchange, its own presence as a new nature that can be crossed only by inhabiting it. $(2002,24)$

The passage above was written before the Tiber transurbance, but seems to describe the relationship between Rome and its riverbanks. A bend in the Tiber, where the calm, shallow water of the river could be easily crossed, was a condition of possibility for the founding of Rome, and is, in this sense, its place origin. Yet the river, embedded in the centre of Rome, is also outside of it. This liminal condition invests the terrain along the riverbanks with particular freedoms, but also with the very real constraints that come along with invisibility, such as a lack of access to clean water and services, barriers to the legitimate job market and obstructed residency papers. 
Stalker’s work navigates a geographic, social and ethical “in-between” zone. They engage territories like the Tiber's riverbanks at considerable risk, but also with considerable potential benefits, to the local inhabitants. In their thirteen years of urban activism in Rome and Europe, Stalker's projects have ranged from long-term mediations between the government and refugee communities to art works such as "Transborderline," an installation that re-interprets the barbed wire spiral that marks national border (Careri, 2001). Their approach to these projects is informed by their practice of the transurbance, in that they insist on an embodied engagement with places and people. Despite the breadth of their work, the goal remains consistent - to work with marginalized communities to help them to gain stewardship, not only over a space but also over their image. 


\section{Bibliography}

Careri, Francesco. "Transborderline." Architectural Design 71.3 (2001): 87-91.

Careri, Francesco. "Walkscapes." Land \& Scape. Ed. Daniela Colafranceschi. Barcelona: Rosello, 2002.

De Certeau, Michel. The Practice of Everyday Life. Berkeley, Los Angeles: University of California Press, 1988.

Debord, Guy. "Theorie de la dérive (1956)." Trans. Libero Andreotti. Theory of the Derive and Other Situationist Writings on the City. Ed. Libero Andreotti and Xavier Costa. Barcelona: Museu d'Art Contemporani de Barecelona/ACTAR, 1958.

Deleuze, Gilles and Felix Guattari. A Thousand Plateaus: Capitalism and Schizophrenia. Trans. Brian Massumi. Minneapolis and London: University of Minnesota Press, 1980, trans.1987.

Dovey, Kim and Kasama Polakit. "Urban Slippage." Loose Space. Ed. Karen A. Franck and Quentin Stevens. New York: Routledge, 2001.

Lang, Peter. "Stalker on Location." Loose Space. Ed. Karen A. Franck and Quentin Stevens. New York: Routledge, 2007.

McDonough, Tom. "Situationist Space." Guy Debord and the Situationist International. Ed. Tom McDonough. Massachussets: MIT Press, 2002.

Purini, Franco. "The Decline of Rome." Roma XX. Ed. Lorenzo Pignatti. Rome and Waterloo: University of Waterloo, 2000. 
Stalker. "Osservatorio Nomade/Stalker". Rome, 2004. www.osservatorionomade.net. April 7 2007.

Stalker. "Stalker: Un Laboratorio Urbane". Rome, 1996. (April 2007): www.stalkerlab.it. April 72007. 